David Brandariz-Núñez ${ }^{1}$ Jessica Gálvez-López²

\title{
Septic arthritis caused by Bacteroides thetaiotaomicrom: A case report and review
}

\author{
${ }^{1}$ Pharmacy Department. Quironsalud Barcelona Hospital. Barcelona. Spain \\ ${ }^{2}$ Microbiology Department. Quironsalud Barcelona Hospital. Barcelona. Spain
}

Article history

Received: 26 April 2021; Revision Requested: 28 May 2021; Revision Received: 15 June 2021; Accepted: 26 July 2021; Published: 5 October 2021

\section{Sir,}

The septic arthritis is an uncommon infection with an incidence of 4 to 12/100,000 person-years. This complication is characterized by the rapid destruction of the joint with loss of function, because of hematogenous spread or direct inoculation of bacteria into the joint [1]. Septic arthritis of the knee is the most frequent location, with catastrophic sequelae and significant associated morbidity and mortality. Arthroscopic surgery and intra-articular injections represent two associated risk factors [2,3]. Polymicrobial etiology is uncommon, with the presence of coagulase-negative staphylococci (CNS) and Staphylococcus aureus, as the main microorganisms involved [4]. In turn, anaerobic bacteria are less common and are related to septic arthritis located in small joints, such as the wrist [5]. Most of the anaerobic microorganisms that cause arthritis are located in the intestinal tract and the origin of the infection is usually by hematogenous spread [6].

We describe the first case of anaerobic septic knee arthritis associated to Bacteroides thetaiotaomicrom in a patient after arthroscopic surgery and periodic knee infiltrations.

A 33-year-old male patient, who underwent reconstruction of the anterior cruciate ligament (ACL) of his left knee in 2015 in Italy. Since then, he has received hyaluronic acid injections every 6 months until the end of 2019. Since mid-February 2020, he had marked inflammation and recurrent joint effusion, requiring 2 evacuating arthrocentesis per week. On March 25, 2020, he came to our center with a fever and persistent effusion in the joint. A magnetic resonance imaging (MRI) was performed where abundant global synovitis and posterior extra-articular edema were observed. Synovial fluid was obtained for analysis and cultivation by arthrocentesis. The joint fluid analysis showed 41,627 leukocytes/mcl, 93.6\% neutrophils and without the presence of crystals. No bacterial growth

Correspondence:

David Brandariz-Núñez

Pharmacy Department. Quironsalud Barcelona Hospital. Barcelona. Spain

E-mail: vrandariz@gmail.com was observed after 5 days of incubation. The patient's general biochemistry revealed an erythrocyte sedimentation rate (ESR) of $37 \mathrm{~mm} / \mathrm{h}$ and a C-reactive protein (CRP) of $3 \mathrm{mg} / \mathrm{dl}$. The following day, arthroscopic intervention for debridement and cleaning was decided, and empiric antimicrobial therapy was started with vancomycin $1 \mathrm{~g} / 12 \mathrm{~h}$ and ceftazidime $2 \mathrm{~g} / 8 \mathrm{~h}$ intravenous. Four samples of synovial exudate extracted during the surgical intervention were sent to culture. Two samples were incubated in conventional plate culture, without microbial growth after five days.

Two subcultures were performed for aerobic and anaerobic organisms from a liquid medium and incubated at $35^{\circ} \mathrm{C}$ in an environment containing $5 \% \mathrm{CO}_{2}$ and anaerobic chamber, respectively. The incubation system was Bact/Alert ${ }^{\circledR}$ (BioMérieux) for five days. in one of the anaerobic samples, the system detected microbial growth after 16 hours of incubation. The anaerobic sample was seeded in medium Schaedler agar (SCS) observing microbial growth, under anaerobic conditions. B. thetaiotaomicrom was identified using the matrix-assisted laser desorption ionization time of flight mass spec-

\begin{tabular}{l|cc}
\hline Table 1 & $\begin{array}{l}\text { Antibiogram of Bacteroides } \\
\text { thetaiotaomicron }\end{array}$ & \\
\hline Antimicrobial & MIC (mg/L) & Susceptibility \\
\hline Amoxicillin-clavulanic & 0.25 & $\mathrm{~S}$ \\
\hline Clindamycin & $>256$ & $\mathrm{R}$ \\
\hline Imipenem & 0.12 & $\mathrm{~S}$ \\
\hline Metronidazole & 0.25 & $\mathrm{~S}$ \\
\hline Cefoxitin & - & $\mathrm{R}$ \\
\hline Chloramphenicol & - & $\mathrm{R}$ \\
\hline Piperacillin-tazobactam & - & $\mathrm{S}$ \\
\hline
\end{tabular}

MIC: minimum inhibitory concentration, R: resistant, S: susceptible 


\begin{tabular}{|c|c|c|c|c|c|c|c|}
\hline Table 2 & Liter & rature review of $\mathrm{Bac}$ & teroides thetaiotao & micron cases. & & & \\
\hline \multirow[t]{2}{*}{ Year/author } & \multirow[t]{2}{*}{ Age/Sex } & \multirow[t]{2}{*}{ Underlying condition } & \multirow[t]{2}{*}{ Type of infection } & \multicolumn{2}{|c|}{ Antibiogram of Bacteroides thetaiotaomicron } & \multirow[t]{2}{*}{ Antimicrobial treatment } & \multirow[t]{2}{*}{ Evolution } \\
\hline & & & & Susceptible & Resistant & & \\
\hline $\begin{array}{l}1990 \\
\text { Patey [11] }\end{array}$ & 51/Female & $\begin{array}{l}\text { Surgery for a genital and } \\
\text { rectal prolapse } 3 \text { months } \\
\text { before }\end{array}$ & Polymicrobial meningitis & & - & $\begin{array}{l}\text { Thiophenicol and } \\
\text { metronidazole }\end{array}$ & Recovery \\
\hline $\begin{array}{l}1996 \\
\text { Funada [12] }\end{array}$ & 42/Female & Acute lymphocytic leukemia & $\begin{array}{c}\text { Polymicrobial sepsis } \\
\text { (neutropenic enterocolitis) }\end{array}$ & Imipenem & $\begin{array}{l}\text { Gentamicin and } \\
\text { ceftazidime }\end{array}$ & Imipenem & Exitus (massive GIB) \\
\hline $\begin{array}{l}2003 \\
\text { Matsukawa [13] }\end{array}$ & 68/Male & $\begin{array}{l}\text { Hepatitis } C_{\text {, alcohol abuser }} \\
\text { whit hepatic cirrhosis }\end{array}$ & Polymicrobial sepsis & & - & Imipenem & Clinic improvement \\
\hline $\begin{array}{l}2005 \\
\text { Feuillet [14] }\end{array}$ & 45/Male & $\begin{array}{l}\text { Hearing loss and } \\
\text { otorrhea for many years. }\end{array}$ & $\begin{array}{l}\text { Cholesteatoma and } \\
\text { meningitis }\end{array}$ & $\begin{array}{l}\text { Amoxicillin- } \\
\text { clavulanic, imipenem, } \\
\text { metronidazole and } \\
\text { clindamycin }\end{array}$ & $\begin{array}{l}\text { Penicillin } \mathrm{G} \text {, cefotetan } \\
\text { and vancomycin }\end{array}$ & $\begin{array}{l}\text { Amoxicillin-clavulanic } \\
\text { and metronidazole }\end{array}$ & $\begin{array}{l}\text { Negative CSF } \\
\text { culture and clinic } \\
\text { improvement }\end{array}$ \\
\hline $\begin{array}{l}2006 \\
\text { Miragliotta [15] }\end{array}$ & 44/Female & Uterine fibromyoma & Post-surgical infection & $\begin{array}{l}\text { Amoxicillin- } \\
\text { clavulanic, imipenem, } \\
\text { metronidazole and } \\
\text { moxifloxacin }\end{array}$ & $\begin{array}{l}\text { Amoxicillin, } \\
\text { piperacillin-tazobactam } \\
\text { and cefoxitin. }\end{array}$ & $\begin{array}{l}\text { Teicoplanin, imipenem } \\
\text { and metronidazole }\end{array}$ & Clinic improvement \\
\hline $\begin{array}{l}2012 \\
\text { Faur [16] }\end{array}$ & 46/Male & $\begin{array}{l}\text { Peritoneal dialysis due to } \\
\text { kidney failure secondary to } \\
\text { cystic kidney disease }\end{array}$ & Peritonitis & & - & $\begin{array}{l}\text { Amikacin, vancomycin } \\
\text { and metronidazole oral }\end{array}$ & $\begin{array}{l}\text { Negative peritoneal } \\
\text { dialysis fluid } \\
\text { culture and clinical } \\
\text { improvement }\end{array}$ \\
\hline $\begin{array}{l}2013 \\
\text { Chao [17] }\end{array}$ & 86/Male & Peritoneal dialysis & Peritonitis & $\begin{array}{l}\text { Chloramphenicol and } \\
\text { metronidazole }\end{array}$ & $\begin{array}{l}\text { Clindamycin and } \\
\text { penicillin }\end{array}$ & Metronidazole & $\begin{array}{l}\text { Recovered } \\
\text { completely }\end{array}$ \\
\hline $\begin{array}{l}2013 \\
\text { Toprak Ülger [18] }\end{array}$ & 62/Male & $\begin{array}{l}\text { Head pancreas } \\
\text { adenocarcinoma }\end{array}$ & Post-surgical bacteremia & $\begin{array}{c}\text { Carbapenems and } \\
\text { ampicillin-sulbactam }\end{array}$ & Metronidazole & Ampicillin-sulbactam & Clinic improvement \\
\hline $\begin{array}{l}2014 \\
\text { Agarwal [19] }\end{array}$ & 56/Male & $\begin{array}{l}\text { Disseminated multiple } \\
\text { myeloma }\end{array}$ & $\begin{array}{l}\text { Posterior spinal wound } \\
\text { infection }\end{array}$ & & - & $\begin{array}{c}\text { Daptomycin, } \\
\text { piperacillin-tazobactam } \\
\text { and metronidazole }\end{array}$ & Cure \\
\hline $\begin{array}{l}2014 \\
\operatorname{Kim}[20]\end{array}$ & 60/Male & Diabetes mellitus & $\begin{array}{l}\text { Polymicrobial mycotic } \\
\text { aneurism }\end{array}$ & & - & Metronidazole & - \\
\hline $\begin{array}{l}2015 \\
\text { Sadarangani [21] }\end{array}$ & 43/Male & Sigmoid diverticulitis & $\begin{array}{l}\text { Post-surgical intra- } \\
\text { abdominal collection }\end{array}$ & Tigecycline & $\begin{array}{l}\text { Clindamycin, } \\
\text { piperacillin- } \\
\text { tazobactam, } \\
\text { ertapenem, } \\
\text { meropenem and } \\
\text { metronidazole }\end{array}$ & Tigecycline & Clinic improvement \\
\hline $\begin{array}{l}2016 \\
\text { Nkamga [22] }\end{array}$ & 41/Male & None & $\begin{array}{l}\text { Chronic paravertebral } \\
\text { muscle abscess }\end{array}$ & & - & Metronidazole & Cure \\
\hline $\begin{array}{l}2019 \\
\text { kalay [23] }\end{array}$ & 16/Male & None & Polymicrobial meningitis & & - & $\begin{array}{l}\text { Metronidazole and } \\
\text { meropenem }\end{array}$ & $\begin{array}{l}\text { Negative CSF } \\
\text { culture and clinic } \\
\text { improvement }\end{array}$ \\
\hline $\begin{array}{l}2020 \\
\text { Kanaujia [24] }\end{array}$ & 15/Male & None & Recurrent otitis media & $\begin{array}{c}\text { Metronidazole, } \\
\text { piperacillin- } \\
\text { tazobactam, } \\
\text { chloramphenicol and } \\
\text { imipenem }\end{array}$ & $\begin{array}{l}\text { Clindamycin and } \\
\text { cefoxitin }\end{array}$ & Metronidazole & $\begin{array}{l}\text { Clinic improvement } \\
\text { and cure }\end{array}$ \\
\hline
\end{tabular}


trometry system (MALDI-TOF MS, VITEK MS ${ }^{\circledR}$, BioMérieux). The susceptibility test was performed with the VITEK $2 X{ }^{\circledR}$ system (BioMérieux). Antibiogram for B. thetaiotaomicrom is shown in table 1. Antimicrobial treatment was modified to piperacillin-tazobactam 4.5g/8h. After 2 weeks of intravenous antimicrobial treatment, the patient was completely afebrile, with a normalized PCR $(0.5 \mathrm{mg} / \mathrm{dl})$ and ESR $(18 \mathrm{~mm} / \mathrm{h})$, with a flexion of the joint of $110^{\circ}$, without effusion, with moderate residual synovitis, mild bone edema and no intra-articular collections on MRI. Hospital discharge was decided with sequential antimicrobial therapy with metronidazole $500 \mathrm{mg} / 8 \mathrm{~h}$, for 2 weeks. A follow-up MRI was performed in July, showing complete resolution of the synovitis and edema. The patient returns to professional activity in October fully recovered.

Anaerobic etiology in septic arthritis of the native joints is infrequent. Despite everything, cases of knee infection caused by Bacteroides fragilis group have been documented $[7,8]$. To our knowledge, this is the first case septic arthritis with isolation of $B$. thetaiotaomicrom. It is an anaerobic, aerotolerant, gram negative, non-sporulated bacillus that is part of the human commensal flora, present in the gastrointestinal and genitourinary tract $[9,10]$. B. thetaiotaomicrom has been described as a pathogen in infections mainly of abdominal origin, postsurgical, meningitis and otitis. It is a very rare anaerobic, all cases reported in the literature are shown in table 2 [11-24]. The presence of concomitant chronic pathologies in more than half of the collected patients may suggest an opportunistic behavior of $B$. thetaiotaomicrom. About the susceptibility profile, an increase in antimicrobial resistance has been reported in the Bacteroides fragilis group in the last two decades [25]. Clindamycin was classically considered the treatment of choice for infections caused by anaerobes. However, the degree of resistance to clindamycin in a study carried out in 13 European countries with 824 clinical isolates has risen to $28-60 \%$ in the Bacteroides fragilis group and specifically to $41 \%$ in $B$. thetaiotaomicrom [26]. Therefore, clindamycin should not be recommended as empirical treatment in infections caused by $B$. fragilis group. In respect of the family of beta-lactams and carbapenems, the emergence of resistance to piperacillin-tazobactam and to a lesser extent to meropenem and imipenem has also been described $[26,27]$. metronidazole, resistance is extremely rare, with only two cases reported in the literature for $B$. thetaiotaomicrom. It is associated with the acquisition of Nim D genes located on chromosomes or plasmids. Resistance rates in the $B$. fragilis group are less than $1 \%$ in studies with multiple clinical isolates $[18,21,26]$. This reduction in the antimicrobial susceptibility confirms the need to always perform susceptibility tests on isolates of Bacteroides fragilis group, since it cannot be assumed that beta-lactams, carbapenems, and metronidazole will always be valid options.

Knee arthroscopy is a common and relatively safe procedure, with an infection rate that varies depending on the series from 0.0009 to $0.4 \%$ [28]. Age $<50$ years, male sex, diabetes, tobacco, complex interventions, and morbid obesity were identified as risk factors related to post-intervention knee infection [29]. Our patient underwent arthroscopic surgery in 2016; therefore, it seems little to proclaim that his septic arthritis is a direct consequence of the intervention. On the other hand, periodic infiltrations may be the main cause of infection. The association between septic arthritis of the knee and the intra-articular administration of corticosteroids is well demonstrated, whereas the injection of hyaluronic acid has not yet been, even though there are cases described in the literature $[3,30]$. The treatment of septic arthritis consists of immobilizing the joint, draining the infected synovial fluid to obtain good control of the infection, and carrying out appropriate antimicrobial treatment with the appropriate duration [31].

In conclusion, septic knee arthritis is an infectious complication that can leave serious consequences. Our patient being the first described case of anaerobic septic arthritis associated with $B$. thetaiotaomicrom. The emerging resistance of $B$. thetaiotaomicrom to carbapenems and metronidazole implies the need to routinely identify and perform susceptibility tests on anaerobic bacteria such as $B$. fragilis group for adequate treatment.

\section{FUNDING}

None to declare

\section{CONFLICTS OF INTEREST}

The authors declare no conflict of interest.

\section{REFERENCES}

1. Mathews $C J$, Weston $V C$, Jones $A$, Field $M$, Coakley G. Bacterial septic arthritis in adults. Lancet. 2010;375:846-55 DOI: 10.1016/ S0140-6736(09)61595-6

2. Balato G, Di Donato SL, Ascione T, D'Addona A, Smeraglia F, Di Vico G, Rosa D. Knee Septic Arthritis after Arthroscopy: Incidence, Risk Factors, Functional Outcome, and Infection Eradication Rate. Joints. 2017;5:107-13 DOI: 10.1055/s-0037-1603901

3. Xu C, Peng H, Li R, Chai W, Li X, Fu J, Liu K, Yu B, Jia C, Chen J. Risk factors and clinical characteristics of deep knee infection in patients with intra-articular injections: A matched retrospective cohort analysis. Semin Arthritis Rheum. 2018;47:911-16 DOI: 10.1016/j.semarthrit.2017.10.013

4. Futterman O, Lieber SB, Nasrullah $\mathrm{K}$, Fowler ML, Shmerling RH, Paz Z. Clinical characteristics of patients with polymicrobial septic arthritis. Eur J Clin Microbiol Infect Dis. 2019;38:1327-1332 DOI: 10.1007/s10096-019-03557-4

5. McBride S, Mowbray J, Caughey W, Wong E, Luey C, Siddiqui A. Epidemiology, Management, and Outcomes of Large and Small Native Joint Septic Arthritis in Adults. Clin Infect Dis. 2020;70:271-79 DOI: 10.1093/cid/ciz265

6. S Snydman DR, Jacobus NV, McDermott LA, Golan Y, Goldstein EJ, Harrell L, Jenkins S, Newton D, Pierson C, Rosenblatt J, Venezia R, Gorbach SL, Queenan AM, Hecht DW. Update on resistance of Bacteroides fragilis group and related species with special attention 
to carbapenems 2006-2009. Anaerobe. 2011;17(4):147-51. DOI: 10.1016/j.anaerobe.2011.05.014.

7. Dubost JJ, Couderc M, Tatar Z, Tournadre A, Lopez J, Mathieu S, Soubrier M. Three-decade trends in the distribution of organisms causing septic arthritis in native joints: single center study of 274 cases. Joint Bone Spine 2014;81:438-40 DOI: 10.1016/j.jbspin.2014.05.001

8. Nolla JM, Murillo O, Narvaez J, Vaquero CG, Lora-Tamayo J, Pedrero S, Cabo J, Ariza J. Pyogenic arthritis of native joints due to Bacteroides fragilis: Case report and review of the literature. Medicine (Baltimore). 2016;95(25):e3962 DOI: 10.1097/ MD.0000000000003962

9. Jousimies-Somer HR, Summanen PH, Wexler H, Finegold SM, Gharbia SE, Shah NH. Bacteroides, Porphyromonas, Prevotella, Fusobacterium, and other anaerobic Gram-negative bacteria. In: Murray PR, Baron EJ, Jorgensen JH, Pfaller MH, Yolken RY, editors. Manual of Clinical Microbiology. Washington DC: ASM Press; 2003. p. 880-901.

10. Lorber B. Bacteroides, Prevotella, Porphyromonas, and Fusobacterium species (and other medically important anaerobic Gram-negative bacilli). In: Mandell GL, Bennett JE, Dolin R, editors. Mandell, Douglas, and Bennett's principles and practice of infectious diseases. Philadelphia, PA: Churchill Livingstone Inc; 2005. p. 2838-46.

11. Patey O, Breuil J, Fisch A, Burnat C, Vincent-Ballereau F, DuBlanchet A. Bacteroides fragilis meningitis: report of two cases. Rev Infect Dis. 1990;12:364-5 DOI: 10.1093/clinids/12.2.364

12. Funada $H$, Shirasaki $H$, Matsuda $T$, Akasofu M. Rhabdomyolysis complicating polymicrobial sepsis in a patient with acute leukemia. Intern Med. 1996;35:36-8 DOI: 10.2169/internalmedicine.35.36

13. Matsukawa $Y$, Kitamura $N$, Kaneko M, Yoshioka D, Miki T, Nishinarita $\mathrm{S}$, et al. Multibacterial sepsis in an alcohol abuser with hepatic cirrhosis. Intern Med 2003;42:208-10 D0I: 10.2169/internalmedicine. 42.208

14. Feuillet L, Carvajal J, Sudre I, Pelletier J, Thomassin JM, Drancourt M, et al. First isolation of bacteroides thetaiotaomicron from a patient with a cholesteatoma and experiencing meningitis. J Clin Microbial. 2005:43:1467-9 DOI: 10.1128/JCM.43.3.1467-1469.2005

15. Miragliotta G, Del Gaudio T, Tajani E, Mosca A. Bacteroides thetaiotaomicron in posthysterectomy infection. Anaerobe. 2006;12:2768 DOI: 10.1016/j.anaerobe.2006.07.002

16. Faur D, Garcia-Méndez I, Martí-Alemany N, Vallès-Prats M. Monomicrobian peritonitis by Bacteroides thetaiotaomicron in peritoneal dialysis patient. Nefrología. 2012;32:694 D0I: 10.3265/Nefrologia.pre2012.Jun.11568

17. Chao C, Liu W, Lai C. Peritoneal Dialysis Peritonitis Caused by Bacteroides thetaiotaomicron. Perit Dial Int. 2013;33: 711-12 DOI: 10.3747/pdi.2012.00229

18. Toprak Ülger N, Sayin E, Soyad A, Dane F, Soyletir G. The first metronidazole-resistant Bacteroides species isolated at Mamara University Hospital: Bacteroides thetaiotaomicron. Microbiyol Bul. 2013;47:717-21. (In Turkish) DOI: 10.5578/mb.5064

19. Agarwal N, Hansberry D, Goldstein I. Infection with Bacteroides thetaiotaomicron during posterior decompression and dynamic stabilization of the lumbar spine: a case report and review of the literature. Int J Neurosci. 2014;124:621-25 DOI: 10.3109/00207454.2013.865618

20. Kim MG, Jeon JW, Ryu IH, Lee JJ, Kim JS, Choi JW, Cho BS, Yoon HJ. Mycotic abdominal aortic aneurysm caused by Bacteroides thetaiotaomicron and Acinetobacter Iwoffii: the first case in Korea. Infect Chemother. 2014;46:54-8 D0I: 10.3947/ic.2014.46.1.54

21. S.P. Sadarangani, S.A. Cunningham, P.R. Jeraldo, J.W. Wilson, R. Khare, R. Patel, Metronidazole- and carbapenem-resistant Bacteroides thetaiotaomicron isolated in rochester, Minnesota, in 2014. Antimicrob Agents Chemother. 2015;59:4157-61 DOI: 10.1128/ AAC.00677-15

22. Nkamga VD, Lotte R, Roger PM, Drancourt M, Ruimy R. Methanobrevibacter Smithii and Bacteroides Thetaiotaomicron Cultivated From a Chronic Paravertebral Muscle Abscess. Clin Microbiol Infect. 2016;22:1008-9 D0I: 10.1016/j.cmi.2016.09.007

23. Kalay GN, Dalgic N, Bozan T, Ulger- Toprak T, Bayraktar B, Soyletir G. Polymicrobial anaerobic meningitis caused by Bacteroides fragilis, Bacteroides thetaiotaomicron, Fusobacterium necrophorum and Slackia exigua in a patient with mastoiditis following otitis media. Anaerobe. 2019;56:95-7 DOI: 10.1016/j.anaerobe.2019.02.003

24. Kanaujia R, Gupta S, Singla N, Jani P, Angrup A. A child with recurrent otitis media due to Bacteroides thetaiotaomicron. Anaerobe. 2020;63:102203. DOI:10.1016/j.anaerobe.2020.102203

25. Hansen KC, Schwensen SA, Henriksen DP, Justesen US, Sydenham TV. Antimicrobial resistance in the Bacteroides fragilis group in faecal samples from patients receiving broad-spectrum antibiotics. Anaerobe 2017;47:79-85 DOI: 10.1016 / j.anaerobe.2017.04.013

26. Nagy E, Urbán E, Nord CE; ESCMID Study Group on Antimicrobial Resistance in Anaerobic Bacteria. Antimicrobial susceptibility of Bacteroides fragilis group isolates in Europe: 20 years of experience. Clin Microbiol Infect. 2011;17(3):371-379 DOI: 10.1111/j.1469-0691.2010.03256.x

27. Snydman DR, Jacobus NV, McDermott LA, Golan $Y$, Goldstein EJ, Harrell $L$, Jenkins $S$, Newton D, Pierson C, Rosenblatt J, Venezia $\mathrm{R}$, Gorbach SL, Queenan AM, Hecht DW. Update on resistance of Bacteroides fragilis group and related species with special attention to carbapenems 2006-2009. Anaerobe 2011;17:147-151 DOI: 10.1016/j.anaerobe.2011.05.014

28. Balato G, Di Donato SL, Ascione T, D'Addona A, Smeraglia F, Di Vico G, Rosa D. Knee Septic Arthritis after Arthroscopy: Incidence, Risk Factors, Functional Outcome, and Infection Eradication Rate. Joints. 2017 Jul 28;5(2):107-113 DOI: 10.1055/s-0037-1603901

29. Clement RC, Haddix KP, Creighton RA, Spang JT, Tennant JN, Kamath GV. Risk factors for infection after knee arthroscopy: analysis of 595,083 cases from 3 United states databases. Arthroscopy 2016; 32 (12):2556-2561 DOI: 10.1016/j.arthro.2016.04.026

30. Shemesh S, Heller S, Salai M, Velkes S. Septic arthritis of the knee following intraarticular injections in elderly patients: report of six patients. Isr Med Assoc J. 2011;13(12):757-760.

31. Mathews $C J$, Kingsley $G$, Field $M$, et al. Management of septic arthritis: a systematic review. Ann Rheum Dis 2007;66:440-5 DOI: 10.1136/ard.2006.058909 